\title{
Trends and Drivers of Refugees in Africa
}

\author{
Miracle Adesina ${ }^{1,2,3 *}$, Muhammad Adeel ${ }^{4}$, Olamide Omigbile ${ }^{5}$, Adesola Abiodun ${ }^{1}$, Emmanuel Adehunoluwa ${ }^{6}$, \\ Ruth Oladele ${ }^{1,2}$, Isaac Olufadewa ${ }^{1,2,7}$, Funmilayo Abudu ${ }^{2,6}$, Ogheneruona Onathoja ${ }^{8}$, Nancy Adeyelu ${ }^{2}$
}

${ }^{1}$ College of Medicine, University of Ibadan, Ibadan, NIGERIA

${ }^{2}$ Slum and Rural Health Initiative Research Academy, Ibadan, NIGERIA

${ }^{3}$ Universal Care for Africa Foundation, St Louis, USA

${ }^{4}$ College of Biomedical Engineering, Taipei Medical University, Taipei. TAIWAN

${ }^{5}$ Bluegate Public Health Initiative, Ibadan, NIGERIA

${ }^{6}$ College of Health Sciences, Obafemi Awolowo University, Ile-Ife, NIGERIA

${ }^{7}$ Pan African University of Life and Earth Sciences Institute, Ibadan, NIGERIA

${ }^{8}$ Faculty of Veterinary Medicine, University of Ibadan, Ibadan, NIGERIA

*Corresponding Author: mayadesina@gmail.com

Citation: Adesina, M., Adeel, M., Omigbile, O., Abiodun, A., Adehunoluwa, E., Oladele, R., Olufadewa, I., Abudu, F., Onathoja, O. and Adeyelu, N. (2022). Trends and Drivers of Refugees in Africa. European Journal of Environment and Public Health, 6(1), em0093. https://doi.org/10.21601/ejeph/11379

ARTICLE INFO

Received: 8 Jul. 2021

Accepted: 28 Sep. 2021

\begin{abstract}
Introduction: Increase in refugees' population poses great political, socio-economic and health challenges to Africa. This study aims to discuss the trends and drivers of refugees in African countries based on their country of origin.

Methods: This study utilized secondary data on the population of refugees in all African countries from 1990 to 2017 based on their countries of origin. The data utilized were compiled by United Nations High Commissioner for Refugee (UNHCR) and analysed using Microsoft Excel 2019, IBM SPSS 25 and Adobe Photoshop CS6.

Results: Seven countries account for about $66.3 \%$ of the refugee population in Africa within 1990 to 2017, five of which are in East Africa. The trend in population of African refugees from 1990 to 2017 can be divided into four phases. Phase one, a sharp decline in refugee population from 1990 till 1992, 1994 till 1997; phase two, a sharp rise in population of refugees' from 1992 till 1994; phase three, a relatively stable period from 1998 till 2011 and phase four, an acute rise from 2011 till 2017 where it peaks. The drivers of African refugee migration are climate change, natural disasters, economic hardship, and violence and tensions.

Conclusion: The refugee population over three decades has been on the rise with occasional periods of decline. This poses great socio-economic and health challenges to the refugees as well as the host countries themselves. It is therefore necessary that the government and other concerned stakeholders create solutions to the causes of this increase in refugee population.
\end{abstract}

Keywords: refugees, migrants, human migration, Africa, population, demographics

\section{INTRODUCTION}

Since the end of World War II, there has been a constant rise in the number of refugees globally (UN, 2019). Fraogmen (1970) explained that this may be due to the constant turbulence in various nations after this era. The global population of refugees rose steadily from 2.8 million in 1976 to about 21.3 million in 2017, including adults and children (UNHCR, 2019). Over 26\% of the global population of refugees is found in Sub-Saharan Africa are found in the Sub-Saharan Africa, the highest population found in any region (UNHCR, 2019). According to the 1951 Refugee convention, a refugee is "someone who is unable or unwilling to return to their country of origin owing to a well-founded fear of being persecuted for reasons of race, religion, nationality, membership of a particular social group, or political opinion” (UNHCR, 2017). However, practically, it is quite difficult to give a definite definition of a refugee (Fraogmen, 1970).

The population of refugees of African origin has been on the rise. This is because of the rise in conflict and violence in Africa (OECD, 2017). This increase in refugee population poses great problems to the continent and the globe at large. These may include health problems in varying diversities (Castaneda et al., 2017), bans on refugee as experienced by the Trump-led administration when he blocked refugees from all countries including three in Africa (Libya, Somalia, Sudan) (Pfortmueller et al., 2012; Whitaker, 2017) and other varying forms of antiimmigrant hostility (Balakian, 2016; Salehyan, 2008; Whitaker, 2016). Examples are the Xenophobia rise in South 


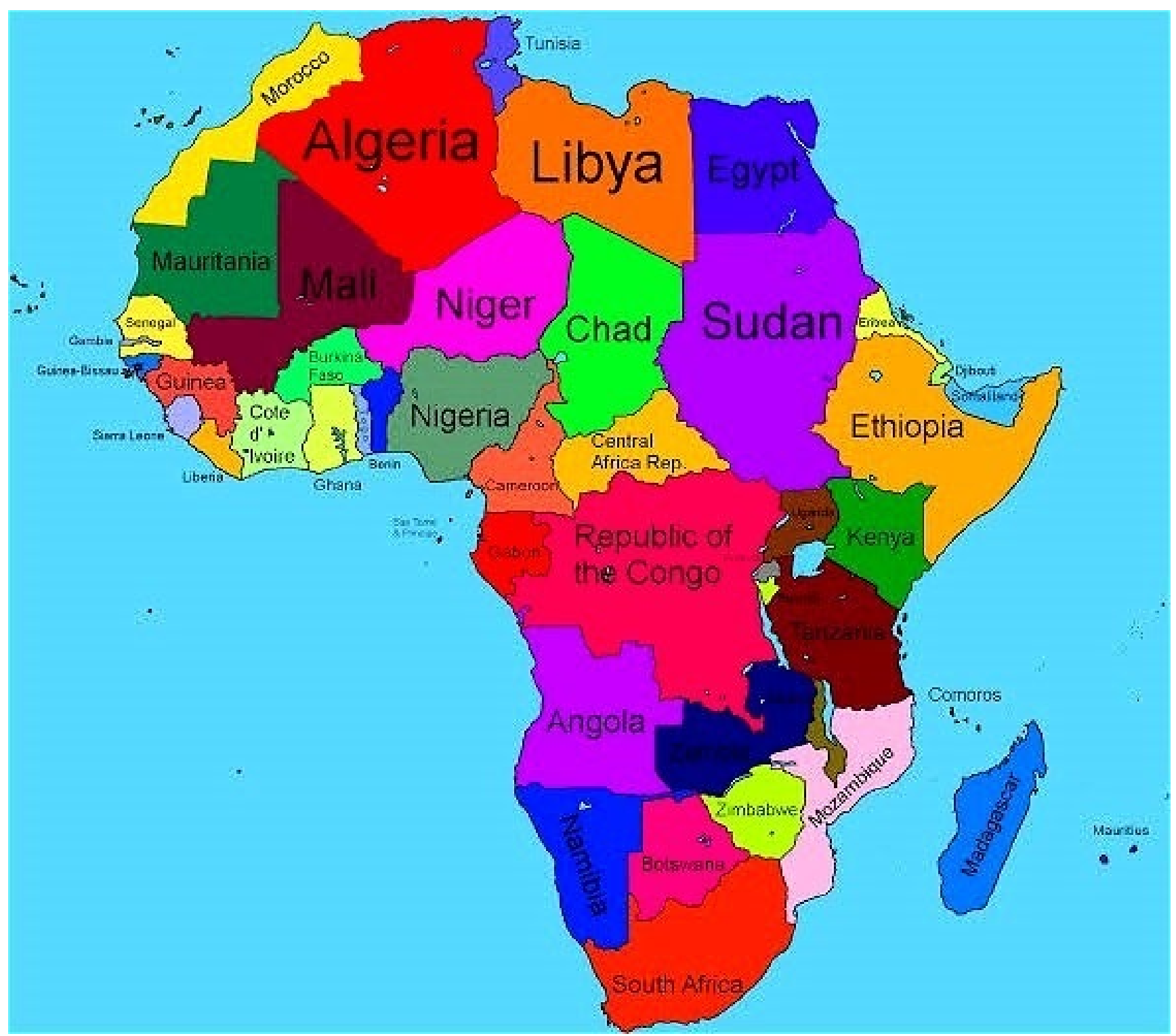

Figure 1. Map of Africa

Source: https://thefutureofeuropes.fandom.com/wiki/African_Breakdown_\%28Map_Game\%29

Africa resulting in violence against Somalis amongst others, the Tanzania government expelling more than half of its Rwandans refugee and the case of the Botswana government refusal to grant refugee status to asylum seekers (Charman, 2012; Kamanga, 2005; Nyamnjoh, 2002; Whitaker, 2017). However, the Sustainable Development Goals (SDGs) allows that forced displacement, as well as the welfare of internally displaced persons and refugees, be considered as development challenges that need greater investment and efforts from the international community (OECD, 2017).

There are 54 countries in the African continent (Figure 1). This study seeks to discuss the population trends of refugees in Africa based on their origin, using secondary data from 1990 to 2017. The outcome of this study may guide governments, policy makers, health advocates, human right activities, nongovernment organisations, etc, in combating issues responsible for the increase in population of refugees in Africa and also in catering for the needs of these refugees. Additionally, this study presents the major drivers for refugee migration in Africa.

\section{METHODOLOGY}

This study utilized secondary data from the World Bank database on the population of refugees in 54 countries in Africa based on their countries of origin from 1990-2017. The data obtained were compiled by UNHCR from numerous sources such as UN Population Division's World Population Prospects, The World Bank, Authorities in Central African Republic, Bureau of Statistics, Ghana, Central Statistical Office of Swaziland, International Monetary Fund, National Bureau of Statistics, among others. The data can be publicly accessed at https://data.worldbank.org/indicator/SM.POP.REFG.OR.

Refugees in this study were defined as people who are recognized as refugees under the 1951 Convention Relating to the Status of Refugees or its 1967 Protocol, the 1969 Organization of African Unity Convention Governing the Specific Aspects of Refugee Problems in Africa, people recognized as refugees in accordance with the UNHCR statute, people granted refugee-like humanitarian status, and people 
provided temporary protection. Country of origin generally refers to the nationality or country of citizenship of a claimant.

\section{Statistical Analysis}

The data from Africa region were extracted into a Microsoft Excel 2019 document and analysed descriptively using SPSS version 25. Adobe Photoshop CS6 was utilized in developing the data visualization (charts and maps). Ethical approval was not required as the data used is publicly available and accessible.

\section{RESULTS}

From 1990 to 2017, there were 118,374,355 refugees from the different regions in Africa as shown in Table 1. The highest population of refugees during this period was from Somalia $(19,217,481)$ and the lowest, from Lesotho (238). Table 1 also categorises nations into different regions viz. North, South, East, West and Central and lists the nations in each region based on decreasing population of refugees.

Figure 2 displays the number of refugees by year from 1990 to 2017 in Africa. The year 2008 had the lowest number of refugees $(2,652,574)$ while 2017 had the highest population $(7,256,662)$. Figure 3 describes the trend of the population of African refugees from 1990 to 2017. The trend during this 28 years period can be divided into four phases. Phase one, a sharp decline in refugee population from 1990 till 1992, 1994 till 1997. Phase two, a sharp rise in population of refugees' from 1992 till 1994. Phase three, a relatively stable period from 1998 till 2011. Phase four, an acute rise from 2011 till 2017 where it peaks.

Seven countries of the 54 countries in Africa account for about $66.3 \%$ of the refugee population in Africa within year 1990 to 2017 (Figure 4). These countries are Somalia $(19,217,481)$, Sudan $(14,211,547)$, Burundi $(10,034,032)$, the Democratic Republic of Congo $(9,521,430)$, Rwanda $(8,666,747)$, Eritrea $(8,495,249)$ and Liberia $(8,433,832)$ respectively. It is of note that 5 out of these 7 countries are in East Africa and account for $77 \%$ of the population of refugees from these groups.

The trend of all 54 countries during the period of 28 years (1990-2017) is presented in Figure 5. Important trends in this chart include; the sharp drop in refugee population from Rwanda between 1994 and 1995, from a staggering 2,257,573 to 574,617 . Also, there was an acute decline in the population of Ethiopian refuges between 1990 and 1991 from 1,316, 636 to 196,242 . However, there was a very rapid rise in the number of Sudanese refugees from 778,718 to a vast $2,439,868$ between 2015 and 2017. Figure 6 presents the population of refugee in the 54 African countries based on the 2017 data.

\section{DISCUSSION}

According to the Office of the United Nations High Commissioner for Refugees (UNHCR, 2019) the world is currently facing the highest levels of displacement ever in history, with an unprecedented 65.3 million people forced to leave their homes as a result of war, conflicts, drought or poor economies. Among these are 21.3 million refugees, over half of
Table 1. Population of refugees from Africa by region, 19902017

\begin{tabular}{|c|c|c|}
\hline $\mathbf{S} / \mathbf{N}$ & Country and Region & Number of Refugee \\
\hline \multicolumn{3}{|c|}{ North Africa } \\
\hline 1 & Egypt, Arab Rep. & 185,031 \\
\hline 2 & Algeria & 177,086 \\
\hline 3 & Libya & 66,769 \\
\hline 4 & Tunisia & 41,387 \\
\hline 5 & Morocco & 41,157 \\
\hline \multicolumn{3}{|c|}{ West Africa } \\
\hline 1 & Liberia & $8,433,82$ \\
\hline 2 & Sierra Leone & $4,011,73$ \\
\hline 3 & Chad & $1,824,18$ \\
\hline 4 & Mali & $1,435,26$ \\
\hline 5 & Mauritania & $1,320,94$ \\
\hline 6 & Cameroon & 191,099 \\
\hline 7 & Guinea & 184,671 \\
\hline 8 & Niger & 105,707 \\
\hline 9 & Nigeria & 991,949 \\
\hline 10 & Togo & 865,198 \\
\hline 11 & Cote d'Ivoire & 809,832 \\
\hline 12 & Senegal & 509,534 \\
\hline 13 & Ghana & 404,105 \\
\hline 14 & The Gambia & 64,607 \\
\hline 15 & Guinea-Bissau & 60,656 \\
\hline 16 & Burkina Faso & 21,062 \\
\hline 17 & Benin & 6,427 \\
\hline 18 & Cabo Verde & 346 \\
\hline \multicolumn{3}{|c|}{ Central Africa } \\
\hline 1 & Congo, Dem. Rep. & $9,521,430$ \\
\hline 2 & Central African Republic & $3,285,089$ \\
\hline 3 & Congo, Rep. & 421,423 \\
\hline 4 & Equatorial Guinea & 9,181 \\
\hline 5 & Gabon & 2,354 \\
\hline 6 & Sao Tome and Principe & 787 \\
\hline \multicolumn{3}{|c|}{ East Africa } \\
\hline 1 & Somalia & $19,217,481$ \\
\hline 2 & Sudan & $14,211,547$ \\
\hline 3 & Burundi & $10,034,032$ \\
\hline 4 & Rwanda & $8,666,747$ \\
\hline 5 & Eritrea & $8,495,249$ \\
\hline 6 & South Sudan & $5,472,996$ \\
\hline 7 & Ethiopia & $4,086,152$ \\
\hline 8 & Uganda & 655,135 \\
\hline 9 & Kenya & 167,750 \\
\hline 10 & Djibouti & 82,027 \\
\hline 11 & Tanzania & 17,835 \\
\hline 12 & Comoros & 5,232 \\
\hline 13 & Madagascar & 4,325 \\
\hline 14 & Seychelles & 1,972 \\
\hline 15 & Mauritius & 1,117 \\
\hline \multicolumn{3}{|c|}{$\begin{array}{r}\text { South Africa } \\
\end{array}$} \\
\hline 1 & Angola & $6,283,458$ \\
\hline 2 & Mozambique & $5,613,141$ \\
\hline 3 & Zimbabwe & 269,570 \\
\hline 4 & South Africa & 53,878 \\
\hline 5 & Namibia & 27,141 \\
\hline 6 & Zambia & 7,414 \\
\hline 7 & Malawi & 3,864 \\
\hline 8 & Botswana & 1,763 \\
\hline 9 & Eswatini & 1,401 \\
\hline 10 & Lesotho & 238 \\
\hline & Total refugee & $118,374,355$ \\
\hline
\end{tabular}




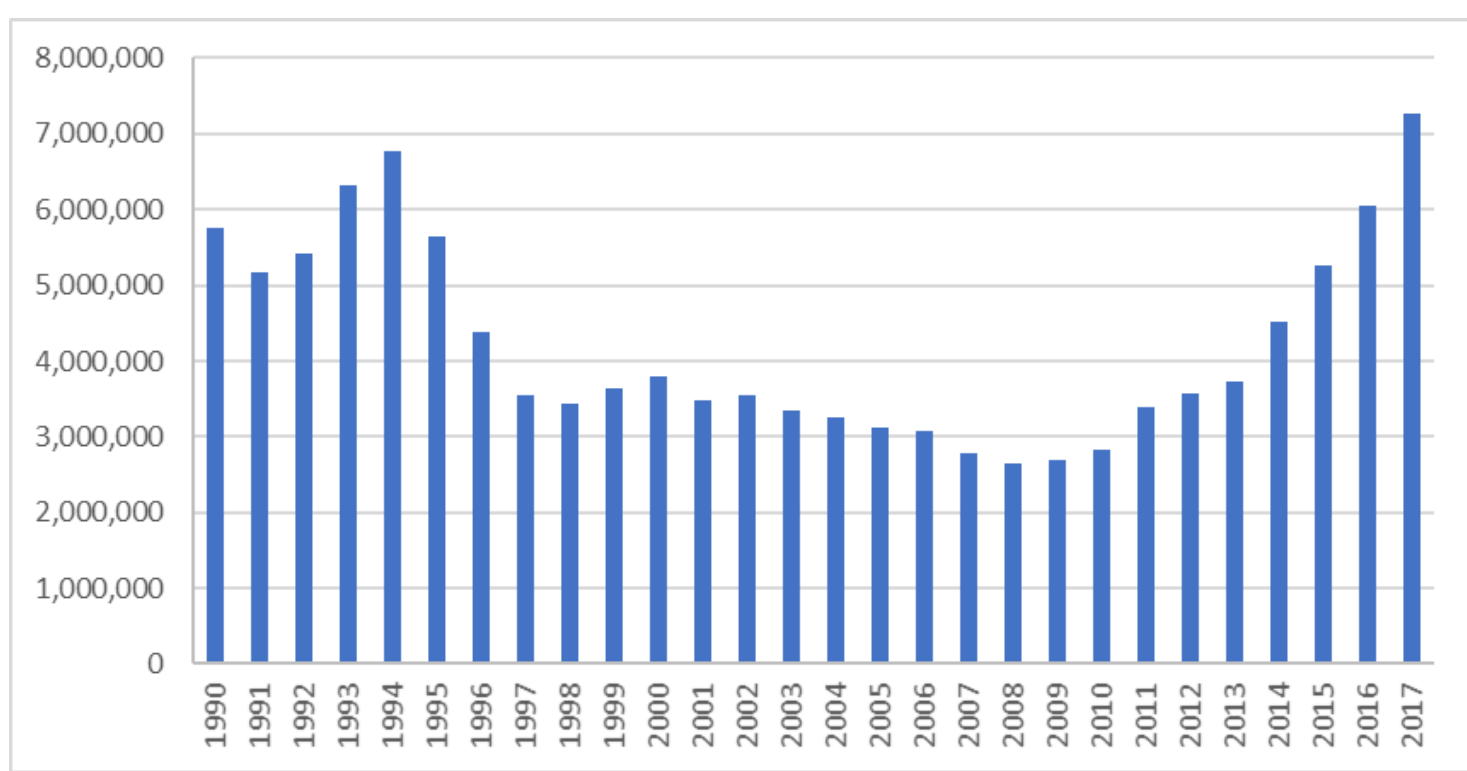

Figure 2. Population of refugees in Africa from 1990- 2017

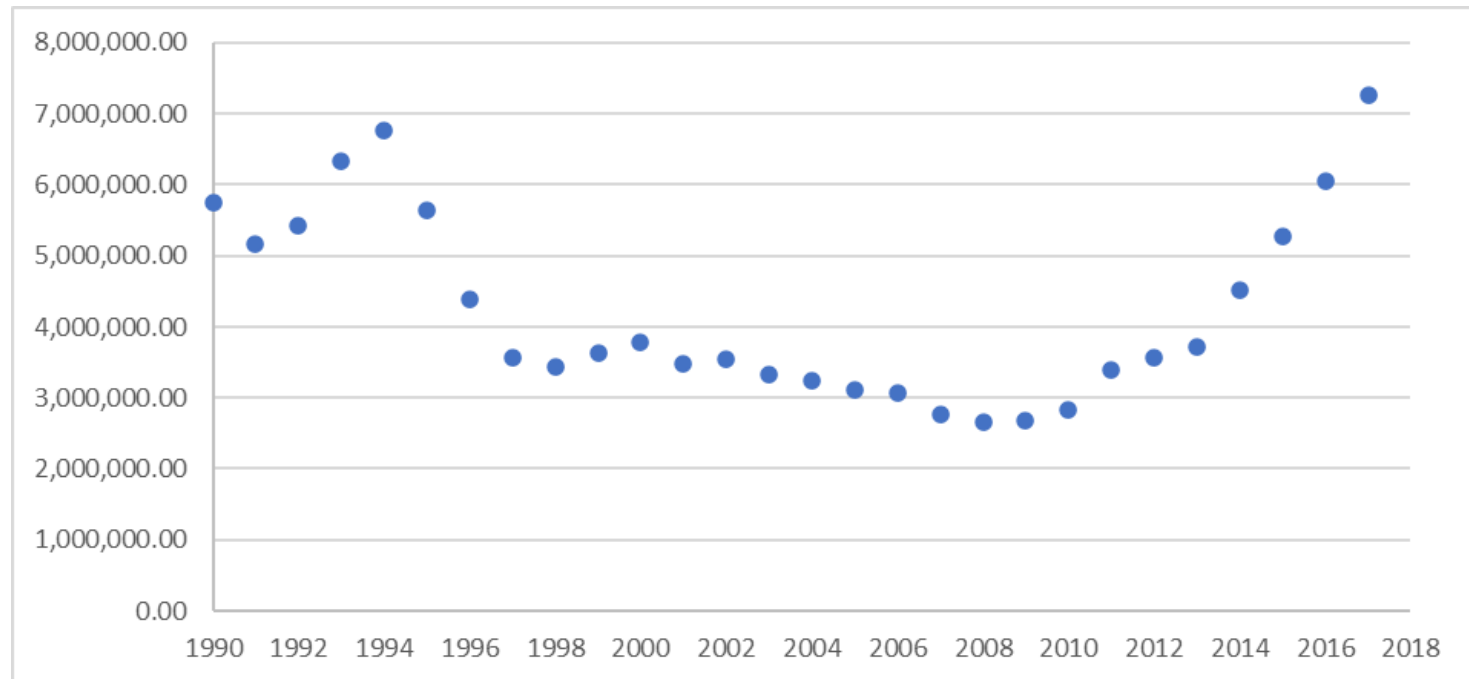

Figure 3. Trend in population of refugee from Africa by year, 1990-2017

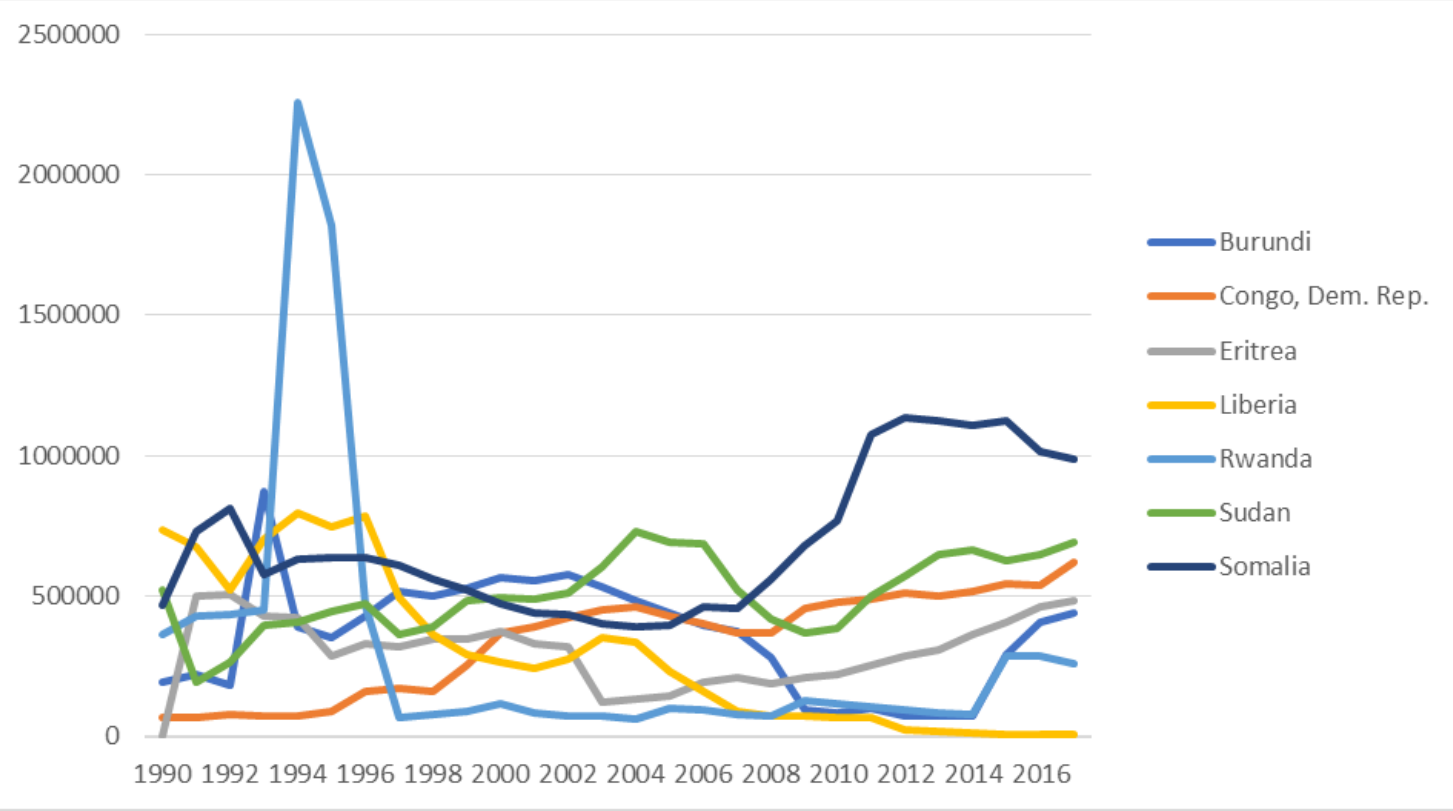

Figure 4. Trend in population of refugees in 7 African countries with highest population of refugees 


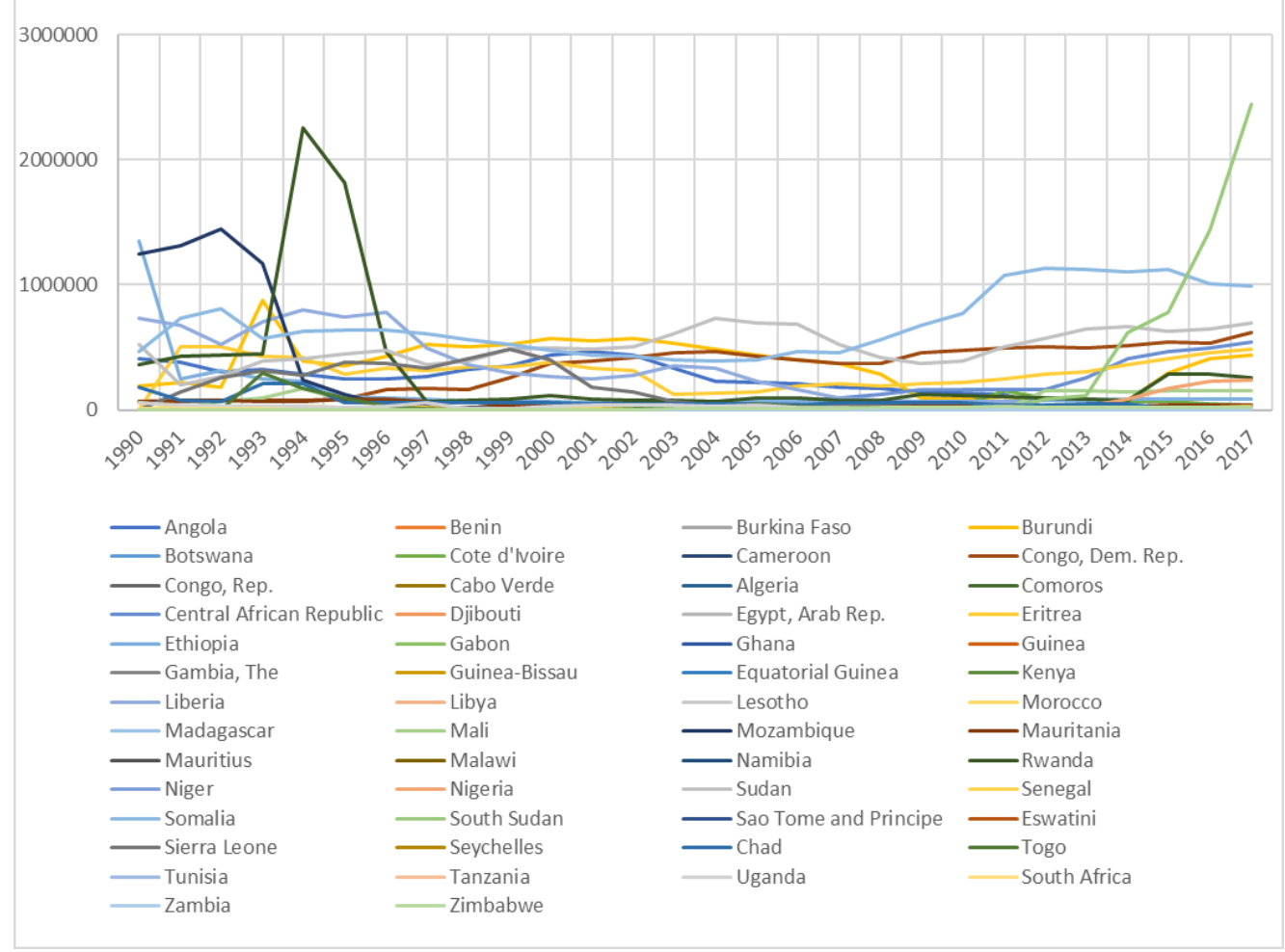

Figure 5. Number of refugees by country of origin, Africa 1990-2017

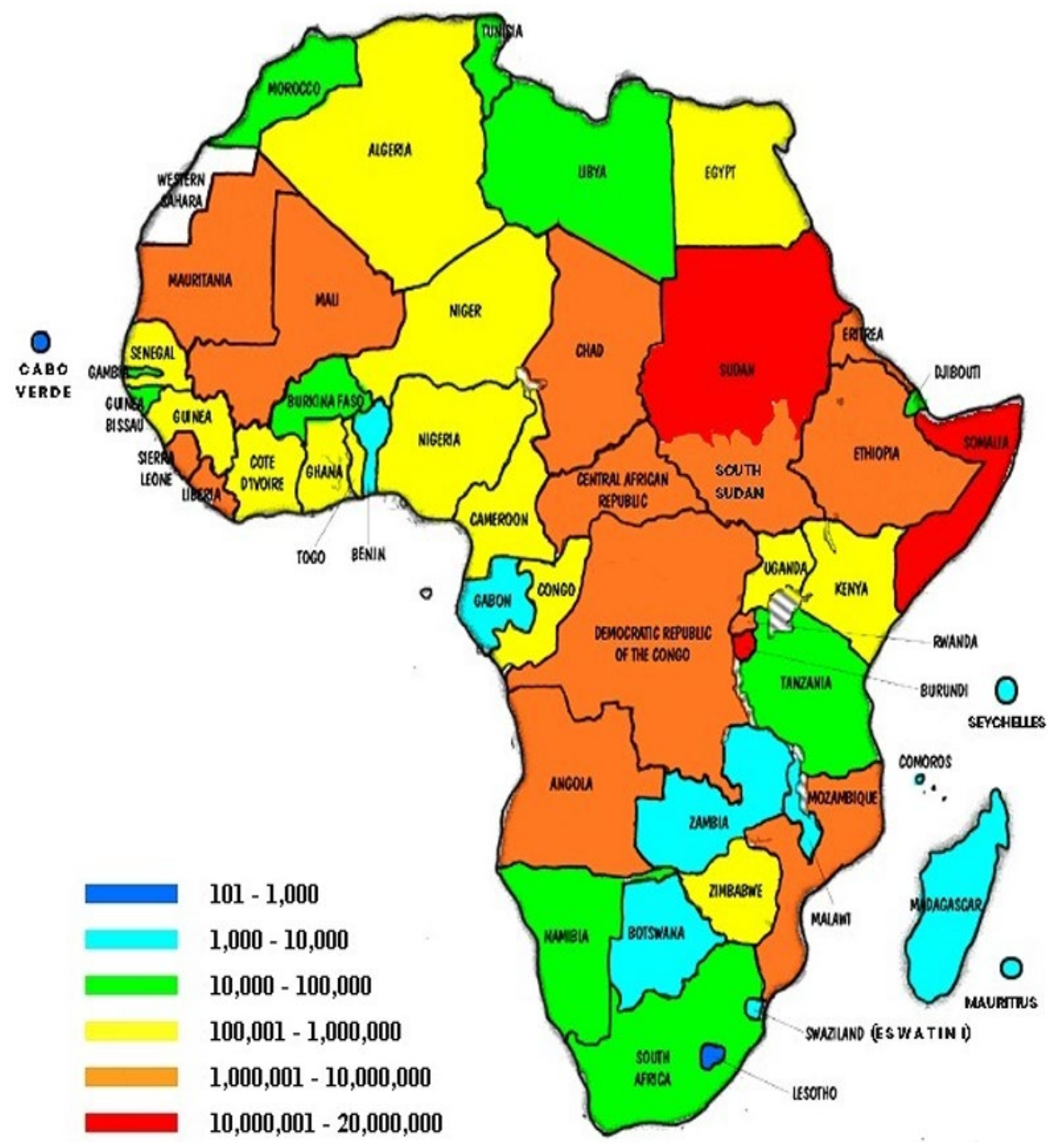

Figure 6. Population of refugees based on the 2017 data 
whom are under the age of 18; the rest are economic migrants and internally displaced persons. Africa contributes a significant number of migrants and refugees due to war and natural disasters on the continent. It is of note that within 2000-2017, Africa accounted for about 14.7 million international migrants making it the second continent after Asia, which had the largest number of international migrants under the year in review (Kumssa et al., 2014).

There was a total of 118,374,355 refugees from the different parts of Africa within the year 1990 to 2017. Somalia accounted for the highest number of refugees under this period. The Somali two decades-long civil war, political instability and the severe droughts in the region resulting in deteriorating humanitarian situation, have forced a great number of Somalis to be refugees, seeking help in neighbouring countries (Polonsky et al., 2014). As of 2017, Somalia alongside Syria, Afghanistan, South Sudan and Myanmar accounted for two-thirds of the world's refugees (UNHCR, 2018). These countries mentioned are all plagued by war and political instability which is responsible for the high number of refugee's population (UNHCR, 2017). East Africa has the highest population of refugees of all the regions in Africa. This high number could be due to climate change and environmental degradation, armed conflict and political and economic crisis (Kumssa et al., 2014).

The year 2017 has been the year with the highest number of refugees from Africa within the time range studied. Probable reasons are mainly due to the South Sudan crisis, the recognition of some number of refugees on a group or prima facie basis, and also the granting of refugee status to quite a number of people (Rutinwa, 2002). The low number of African refugees in 2008 can be attributed to successful voluntary repatriation of a great number of refugees (UNHCR, 2019). This repatriation also occurred in the Asia and East Pacific region leading to a decline in refugee population (UNHCR, 2019). The sharp decline in refugee population from 1990 to 1992 and 1994 to 1997 can be due to certain factors. During this period, certain countries, for example, Tanzania and Zaire closed their borders against refugees (Rutinwa, 2002). Countries, such as Kenya and Tanzania also ordered forceful repatriation of refugees on the grounds that their presence was compromising the security of the country (Rutinwa, 2002). Also, the sharp rise from 2011 to 2017 can be because of rise in conflict and violence, political crisis and economic instability brewing in some African countries (UNHCR, 2017).

The notable trends presented are the sharp drop in refugee population in Rwanda between 1994 and 1995 and Ethiopia between 1990 and 1991 and also the sharp rise in population of refugees from Sudan between 2015 and 2017. In the 1994 and 1995 periods, there was forced repatriation of millions of Rwandese refugees from Tanzania and the then Zaire. This may have accounted for the sharp decline in refugee population during that period (Rutinwa, 2002) while the probable reasons for the sharp rise in Sudan during the periods of 2015- 2017 may be due to the peak experienced in the South Sudan crisis (UNHCR, 2017).

\section{Drivers of African Refugee Migration}

\section{Climate change}

Climate change has become one of the major causes of human displacement in Africa (UNHCR, 2019) as it has caused a rapid increase in the population of refugees (Environmental migration, 2020) because of its devastating effects on human existence. Such effects include; limitation in natural resources, food insecurity, poor nutrition and hygiene, lack of healthcare facilities, amongst others (UNHCR, 2019).

In a bid to survive, people tend to fight over the few available resources resulting in violent attacks among communities, forcing people to get displaced across international borders (UNHCR, 2019). Also, people who have been formerly displaced (primary displacement) because of other reasons, migrate to climate change affected areas and this can further force them into a secondary migration (UNHCR, 2019). Though, the refugees hardly contribute to the generators of climate change, they are mostly impacted by its consequences (Ahmed, 2019).

\section{Natural disasters}

Natural disasters have also been an impetus for human migration across borders in many African countries (UN, 2020). Disasters such as famines, floods, droughts, cyclones, mudslides and landslide, which may or may not be due to climate change, have affected different parts of the continent (Basher, 2008; UN, 2020). It has also caused negative socioeconomic impacts on the affected regions leading to poor quality of life of the inhabitants, subsequently forcing them to leave their homelands in pursuit of survival. The eastern part of the continent has been mostly hit by the effects of natural disasters as it experienced persistent drought for several years (Basher, 2008). This resulted in a higher number of refugee population in this region as revealed by this study.

\section{Economic hardship}

Most African countries declared independence from colonial empires in the post-World War II era, with little or no infrastructure available for manufacturing, education or healthcare, nor did they have much experience with running a modern state apparatus (Easterly, 2002). The World Bank stated in its 2019 report that 24 of the 30 countries in the world with annual per capita incomes (GDP per capita, current international USD) less than 3000 USD are in Africa, and these figures do not even include the conflict-ridden countries like Somalia and South Sudan (World Bank, 2019). The role of economic hardship in African refugee migration is impossible to disregard. Zelinsky (1971), in his Hypothesis of the Mobility Transition, argued that processes of modernisation and economic development historically resulted in increasing rural-to-urban migration followed by a subsequent increase in emigration. The wealth of a society has an inverse relationship to its emigration rate and a linear relationship with its immigration rate. However, as seen in most African countries, the presence of refugees places a demand on an already overstretched economy. Economic development of African societies would not only encourage citizens to imagine a future in their home countries, but would also foster conditions that will spur refugees to return to their homes at their own will. 


\section{Violence and tensions}

Violent conflicts have been figured as one of the predominant causes of African refugee migration. The Office of the United Nations High Commissioner for Refugees (UNHCR) stated that the world is currently facing the highest levels of displacement ever in history, with an unprecedented 65.3 million people forced from their homes by war and internal conflict (UN, 2019). It was further revealed that the rate of human displacement is 34,000 per day due to conflict or persecution. In the Central African Republic, clashes among rival groups have forced thousands to flee their homes. Likewise in Nigeria, over 2 million people have been forcibly displaced, including the 1.87 million who have fled from the militant group Boko Haram's violence since 2014 (Momodu, 2017). Although the UN General Assembly High-Level Meeting on Refugees and Migrants addressed large movements of refugees and migrants, critics, however, say that the UN summits spent little time addressing the root causes of forced displacement and insecurities that force people to flee (Momodu, 2017). Poverty, poor education, unemployment, tribalism/racism and gross inequality of incomes can be identified as the causative factors for violence and tensions.

\section{Limitations}

This study may have been limited by under-reporting of data in many African countries.

\section{Recommendations}

A lot still needs to be done especially by the destination states in offering international protection for the rights of people displaced by climate change and natural disasters as most destination states do not recognise refugees in such context (Thompson, 2019). Also, the health status of the refugees should be of utmost importance as they are at risk of communicable diseases such as HIV/AIDS, sexually transmitted diseases, etc (Adesina et al., 2020; Olufadewa et al., 2020). Some of these diseases can be prevented by availablility of healthcare services and proper education on sexual health, contraceptive use, and so on (Adesina et al., 2020). Mental health and psychosocial supports should be provided for the refugees (Adesina et al., 2020a, 2020b). It is recommended that further studies should be conducted on the effect of migration and displacement on the health status of refugees in Africa (Olufadewa et al., 2020).

\section{CONCLUSION}

The refugee population over three decades has been on the rise with occasional periods of decline. This poses great socioeconomic and health problems to the refugees as well as the host countries themselves. It is therefore necessary that the government and other concerned stakeholders create lasting solutions to the causes of this increase in refugee population by tackling the drivers of the migration.

Author contributions: All co-authors were involved in all stages of this study while preparing the final version. They all agree with the results and conclusions.

Funding: No external funding is received for this article.
Declaration of interest: The authors declare that they have no competing interests.

Ethics approval and consent to participate: Not applicable. Availability of data and materials: All data generated or analyzed during this study are available for sharing when appropriate request is directed to corresponding author.

\section{REFERENCES}

Adesina, M. A. (2020). An overview of the health status and demographics of a conflicting country: the Sudan experience. European Journal of Environment and Public Health, 4(1), em0032. https://doi.org/10.29333/ejeph/5933

Adesina, M. A. and Olufadewa, I. I. (2020). Comprehensive Sexuality Education (CSE) curriculum in 10 east and southern African countries and HIV prevalence among the youths. European Journal of Environment and Public Health, 4(1), em0035. https://doi.org/10.29333/ejeph/6009

Adesina, M. A., Adesanya, T. B. and Olufadewa, I. I. (2020). Mental health and conflict in Nigeria: An overview. European Journal of Environment and Public Health, 4(1), em0038. https://doi.org/10.29333/ejeph/7806

Adesina, M. A., Oladele, R. I. and Olufadewa, I. I. (2020). Mental health and psychosocial support in conflicting Nigeria. Yenegoa Medical Journal, 2(4), 15-23.

Ahmed, M. (2019). How climate change exacerbates the refugee crisis-and what can be done about it. World Economic Forum. Available at: https://www.weforum.org/ agenda/2019/06/How-climate-change-exacerbates-therefugee-crisis-and-what-can-be-done-about-it

Balakian, S. (2016). Money is your government: Refugees, mobility, and unstable documents in kenya's operation usalama watch. African Studies Review, 9(2), 87-111. https://doi.org/10.1017/asr.2016.36

Basher, R. (2008). Disasters and what to do about them. Forced Migration Review, 31, 35-36. Available at: https://www.fmreview.org/climatechange/basher

Castaneda, A. E., Junna, L., Lilja, E., et al. (2017). The prevalence of potentially traumatic pre-migration experiences: A population-based study of Russian, Somali and Kurdish Origin Migrants in Finland. Journal of Traumatic Stress Disorders \& Treatment, 6(1). https://doi.org/10.4172/2324-8947.1000165

Charman, A. and Laurence, P. (2012). Xenophobia, criminality and violent entrepreneurship: Violence against Somali shopkeepers in Delft South, Cape Town, South Africa. South African Review of Sociology, 43(3), 81-105. https://doi.org/10.1080/21528586.2012.727550

Easterly, W. (2002). The elusive quest for growth: Economists' adventures and misadventures in the tropics. Massachusetts: MIT Press. https://mitpress.mit.edu/books/elusive-questgrowth

Environmental migration. (2020). Available at: https://migra tiondataportal.org/themes/environmental_migration 
Fragomen Jr, A. T. (1970). The Refugee: a problem of definition. Case Western Reserve Journal of International Law, 3(1), 45-70. Available at: https://scholarlycommons. law.case.edu/jil/vol3/iss1/4/

Kamanga, K. (2005). The (Tanzania) refugees act of 1998: Some legal and policy implications. Journal of Refugee Studies, 18(1), 100-116. https://doi.org/10.1093/jrs/18.1.100

Kumssa, A., Williams, J. H., Jones, J. F., et al. (2014). Conflict and migration: The case of Somali refugees in Northeastern Kenya. Global Social Welfare, 1, 145-156. https://doi.org/10.1007/s40609-014-0006-9

Loescher G. (1993). Beyond Charity: international cooperation and the global refugee crisis. Oxford: Oxford University Press. Available at: https://global.oup.com/academic/ product/beyond-charity-international-cooperation-andthe-global-refugee-crisis-9780195102949

Momodu, S. (2017). Africa most affected by refugee crisis. Africa Renewal, 30(3), 28. https://doi.org/10.18356/ d77f1bad-en

Nyamnjoh, F. B. (2002). Local attitudes towards citizenship and foreigners in Botswana: An appraisal of recent press stories. Journal of Southern African Studies, 28(4), 755-775. https://doi.org/10.1080/0305707022000043502

Olufadewa, I. I., Adesina, M. A, Ayorinde, T. and Oladele, R. I. (2020). Reimagining one health in Africa: A strategy for ending re-emerging infections and antimicrobial resistance. International Journal of Health Planning and Management, 5(3), 2-4. https://doi.org/10.1002/hmp.3069

Olufadewa, I. I., Adesina, M. A. and Ayorinde, T. (2020). From Africa to the World: Reimagining Africa's research capacity and culture in the global knowledge economy. Journal of Global Health, 10(1), 010321. https://doi.org.10.7189/jogh.10.010321

Organisation for Economic Co-operation and Development. Responding to Refugee Crisis in Developing countries. What we can learn from evaluations? 2017. Available at: http://www.oecd.org/newsroom/

Pfortmueller, C. A., Graf, F., Tabarra, M., et al. (2012). Acute health problems in African refugees: ten years' experience in a Swiss emergency department. Wiener Klinische Wochenschrift, 124(17-18), 647-652. https://doi.org/ 10.1007/s00508-012-0227-9

Polonsky, J. A., Ronsse, A. and Ciglenecki, I. (2013). High levels of mortality, malnutrition and measles, among recentlydisplaced Somali refugees in Dagahaley camp, Dadaab refugee camp complex, Kenya, 2011. Conflict and Health, 7(1), 1. https://doi.org/10.1186/1752-1505-7-1
Rutinwa, B. (2002). The end of asylum? The changing nature of refugee policies in Africa. Refugee Survey Quarterly, 21(1-2), 12-41. https://doi.org/10.1093/rsq/21.1_and_2.12

Salehyan, I. (2008). The externalities of civil strife: Refugees as a source of international conflict. American Journal of Political Science, 52(4), 787-801. https://doi.org/10.1111/ j.1540-5907.2008.00343.x

The World Bank International Comparison Program Database (2019). Population Growth. The World Bank. Available at: https://data.worldbank.org/indicator/SP.POP.GROW?year _high_desc=true

Thompson, B. (2019). Climate change and displacement. Available at: https://www.unhcr.org/news/stories/2019/ 10/5da5e18c4/climate-change-and-displacement.html

United Nations High Commissioner for Refugees. (2008). Report of the United Nations High Commissioner for Refugees covering the period from 1 January 2007 to 30 June 2008. Available at: https://www.unhcr.org/excom/unhcrannual/ 492d1f6a2/report-united-nations-high-commissionerrefugees-2007-covering-period-1.html

United Nations High Commissioner for Refugees. (2011). Situation report: Dadaab Refugee Camps. Available at: http://reliefweb.int/sites/reliefweb.int/files/resources/Full _Report_2923.pdf

United Nations High Commissioner for Refugees. (2017). Global trends, forced displacement in 2017. Available at: https://www.unhcr.org/globaltrends2017

United Nations High Commissioner for Refugees. (2018). Global trends, forced displacement in 2018. Available at: https://www.unhcr.org/globaltrends2018

United Nations High Commissioner for Refugees. (2019). Climate change and disaster displacement. Available at: https://www.unhcr.org/climate-change-anddisasters.html

United Nations Refugees and Migrants. Definitions. (2019). Available at: https://refugeesmigrants.un.org/definitions/

United Nations, Refugees. (2020). https://www.un.org/en/ sections/issues-depth/refugees/

Whitaker, B. E. (2016). The politics of closing refugee camps. Political violence at a glance. Available at: https://politicalviolenceataglance.org

Whitaker, B. E. (2017). Migration within Africa and beyond. African Studies Review, 60(2), 209-220. https://doi.org/10.1017/asr.2017.49

Zelinsky, W. (1971). The hypothesis of the mobility transition. Geographical Review, 61, 219-249. https://doi.org/10.2307/ 213996 